\title{
Violence Against Women: The Treatment In The Spanish Criminal Law
}

\author{
Silvia Valmaña Ochaíta, Ph.D., University of Castilla-La Mancha, Spain
}

\begin{abstract}
In the last years we have been witnesses of how the legal reforms about gender violence have been followed one another in Spain, and how they were fruitful in the social conscience. Nevertheless, the legal effectiveness of the reforms is still questioned, the judicial decisions often are contradictory, and the violence level is greater than ever or, at least, more visible. This work tries an approach to the study of this matter throw the legislative evolution, analyzing the lights and shadows of the Spanish Criminal System.
\end{abstract}

Keywords: Gender Violence, Spanish Criminal Code

\section{INTRODUCTION}

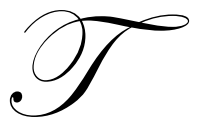

he fact that women, throughout History, have been preferential and habitual victims of many crimes is something amply known (Larrauri, 2007). The perception of women as victims has been changing in the societies and, therefore, in the legislations, is also a contrasted fact (Valmaña, 2000). The idea of rape as the most serious insult to the familiar honor, and the current conception of such crime as the attack of sexual freedom, is the most evident sample of understanding changes in this crime (Valmaña, 2010-a).

Therefore, the current regulation of the crimes that are more directly and specific related to the protection of the women, as more frequent victims, or those crimes that, in a general way, are often linked with this phenomenon of the violence against women, must be object of treatment and analysis (Alcale, 1999).

The same could be said about old people and the children. There are not many things more frightful than you could not feel out of danger even in your own home; or that your refuge becomes the place where your aggressor has you at his mercy. The mechanisms for the protection of these people, especially vulnerable by the situation in which they are, and their relation with the attacker, would exceed nevertheless this brief analysis of the Spanish reality. Among others, the generic crimes in which can be appreciated a more direct connection with the domestic violence, in general, and against the women, in particular, are the crimes against the life, physical and moral integrity, the freedom and sexual indemnity, and the crimes against the familiar relations, among others.

In some cases, like homicide (Article 138 Spanish Criminal Code: "He who kills another will be punished, as a defendant of homicide, with a prison sentence of ten to fifteen years") the fact that the death takes place within the affective familiar relationship, does not really add any consideration to the Criminal type. Only through the circumstance of kinship (Article 23 of Spanish Criminal Code: "It is possible to attenuate or aggravate the criminal responsibility, according to the nature, the reasons and the effects of the crime, when the offended is or has been spouse or a person tied to a permanent relationship by analogous affective relationship, or to be ancestor, descendant or brother by nature or adoption of the offender or his/her spouse or partner"), the behavior deserves of a greater punishment.

In others, nevertheless, the attempts of reducing more and more the chilling number of cases in which the violence in the family is pronounced of the most brutal way brought on the introduction or reform of crimes which facilitated the chasing or increased the punishment of those behaviors. These crimes, and more specifically of the crime of abuse, whereas they are the offences on which the violence in the familiar relations articulates fundamentally, and therefore the one which has attracted more the reformer activity of the criminal legislator in the 
last time. The Spanish criminal legislation has suffered serious changes in this matter during these last decades; and it can give an idea about the importance of the subject. But in addition these changes show the vacillating attempts to solve the problems and the different tried methods could appear as a good intentioned more than an effective legislator. The object of this essay is the analysis of the policies of prevention and repression of violence against women in Spanish Law throw a brief route by its evolution.

\section{THE EVOLUTION OF THE SPANISH LAW}

First and foremost, I must say that the Spanish method for the abuse crime prevention has been over all the try and error method. The well-intentioned legislator tries a rule to avoid the increasing of the violence against women, and the reality becomes worse than is expected, so a new Law appears to change the weak points of the previous law. The problem is that all the Spanish Criminal Code reforms have been made in a few years, perhaps without time enough to study the actual repercussions of the Law. Perhaps this is one of the causes for the unsatisfactory taste of the legal evolution in this matter in Spain. The institutes and observatories ${ }^{1}$ on this matter have a controversial position, as official institutions and linked to the Govern and sometimes docile servants of the official view.

\subsection{Organic Law 3/1989, June $21^{\text {st }}$, to update Criminal Code.}

The Preamble of this Law says that the appearance of the crime of abuse in the Spanish legal ordering takes place "responding to the deficient protection of the physically weaker members of the familiar group front to systematically aggressive behaviors of other members, defined as crime the abuse exercised on incapables or minors, as well as the exercised on the spouse when, even if individually considered they do not integrate more than a succession of misdemeanours, they take place of habitual way". The article 425 of the Criminal Code gathers for the first time the crime of abuse establishing that "he who habitually and with any purpose, exercises physical violence on his spouse or person whom was united by analogous affective relationship, as well as on the children under patria potestas, or pupil, minor or incapable under his/her tutelage or guardianship, will be punished with the punishment of arrest for a period from one to six months". Also, the behavior is contemplated like misdemeanour against the article 582 of the Criminal Code to strike or to mistreat to another one without causing injury to him whenever the spouse or person whom is linked the author in a permanent way by analogous affective relationship, or the minor. In this initial regulation the elements that integrate the crime and the misdemeanour of abuse are the relation of kinship, the physical violence and the habitual.

\subsection{Organic Law 10/1995, November $23^{\text {rd }}$, Spanish Criminal Code.}

The appearance of the new Criminal Code supposed an advance in the regulation of the crimes of abuse in different aspects. On the one hand, the relation of passive subjects of the crime of the article 153, direct heir of old article 425 , gets wider as in relation to the descendants as with the ancestors, even with the coexistence requirement. On the other hand, the prison sentence of a month and a day to six months in the article 425 of the previous Criminal Code, rises in a substantial way, and now is from 6 months and a day to three years (article $153 \mathrm{CP}$ ). It is especially significant the appearance of the reference to the possibility of establishing multiple criminal offences, when includes the possibility of considered abuse crime notwithstanding of the qualification that deserves the concretion of the exercised acts of violence (Valmaña, 2000).

\subsection{Organic Law 14/1999, June $9^{\text {th }}$, modification of the Criminal Code of 1995 , on protection for the victims of abuse, and of the Law of Criminal Procedure.}

The Preliminary recitals of this Law establishes that "the action plan against the domestic violence, approved by Agreement of the Cabinet, April, $30^{\text {th }}$, of 1998, included among the adopted measures some legislative actions directed to the modification of the Criminal Code and the Law of Criminal Procedure, in order to obtain the

\footnotetext{
${ }^{1}$ The most representative institutions in this matter are the Observatory Against Domestic Violence And Gender-Based Violence, depending on the General Council of the Judiciary, and the State Observatory Of Violence On Women, depending on the Ministry for Health, Social Policy and Equality.
} 
eradication of the criminal behavior of abuse, at the same time to get a greater and better protection to the victims of so deplorable conducts", which materialized in the reform of articles 33, 39, 48, 57, 83, 105, 153, 617 and 620 of the Criminal Code. The most significant innovations are the appearance in the catalogue of accessory penalties, the prohibition of approach to the victim. Furthermore is typified as a crime the habitual exercise of the psychic violence in the domestic sphere, and settles down the first authentic interpretation of the term habitual Moreover, the new modification authorizes for the exercise of the criminal action ex-officio in the case of a misdemeanour (Cortes, 2000).

\subsection{Organic Law 11/2003, of 29 of September, with concrete measures in the matter of citizen security, domestic violence and social integration of foreigners.}

This Law of heterogeneous content an undecided systematic indicates in the Preliminary recitals that "the phenomenon of the domestic violence has certainly a multidiscipline scope. It is necessary to deal it with preventive measures, care and welfare measures, and social intervention carried out in favor of the victim, with measures to incentive the research, and also with legislative measures oriented to prevent these crimes". The Law introduces relevant modifications relating to the appearance of the genital mutilation as an independent crime, the extension of the scope of application of the battery, with the transformation the misdemeanour of battery contained in article 617 of the Spanish Criminal Code, in a felony of battery (article 147 S.C.C.). It will happen when four misdemeanour of battery had been made in a period of one year; the reform also introduces some accessory penalties for the crime of abuse (privation of the right of possession and carry arms, and possibility that the judge or the court decides to deprive of patria potestas, tutelage, guardianship or fostering of children). But certainly the most relevant modification appears with the introduction of the article 173,2 and 3 of Spanish Criminal Code, which typify the habitual physical and also psychic violence behavior as a crime against moral integrity.

\subsection{Organic Law 1/2004, of 28 of December, of Measures for the Integral Protection against the Gender Violence.}

The Preliminary recitals of this Law establish that "the gender violence is not a problem that affects only the private sphere. On the contrary, it is pronounced like the most brutal symbol of the existing inequality in our society. One is a violence that goes on the woman by the same fact of being it, for being considered by her aggressor lacking of the minimum rights of freedom, respect and capacity of decision". Elaborated from obvious feminist postulates (Faraldo, 2006), this Law introduces some of the most outstanding and controversial new features in this matter. In the first place it is possible to indicate that the article 1 of the Law establishes with the already seen concept of violence, another element to consider which is the technical definition of the battered woman syndrome: "the aggressions borne by the woman resulting of the social and cultural conditioners acting on the masculine and feminine gender, placing her in a subordinated position to the man, and expressed in the three basic spheres of a personal relation: abuse in the couple relations, sexual aggression in the public life, and moral harassment (mobbing) in labor". From this point takes place the conversion of different abuse behaviors in concrete crimes of gender violence.

\subsection{Organic Law $\mathbf{5} / 2010$, of 22 of June, modification of the Criminal Code of 1995 .}

This Law only affects the criminal protection against the gender violence in an indirect way. There are two spheres in which they take place the manifestations of such gender violence, and both have now an express typification. The Preliminary recitals of this Law of the Law indicate that "the mobbing is incriminated within the crimes of tortures and against moral integrity, understanding mobbing as the psychological or hostile harassment within the framework of any labor or civil service job, imposing a situation of serious offense to the dignity that humiliates whom bears it. So all the harassment behaviors in the sphere both public law and private law relations would be incorporated in the criminal type".

\section{CONTROVERSIAL MATTERS ON THE JURISPRUDENCE}

The capital matters in the regulation of the abuse crime in Spanish Law are linked to the constitutional insertion of the typification of the behavior. First, the felony is referred to a unique victim, the woman. This special 
condition has become the main controversial question for a long time. The first submission for unconstitutionality in this matter was promoted by the Criminal Court, number 4 of Murcia. The argument was that the specific protection for the woman in the Organic Law 1/2004 was against the equality principle, established in the article 14 of the Spanish Constitution. The answer came with the Sentence of the Plenary of the Constitutional Court, n. 59/2008 of May, the $14^{\text {th }}$ in which it is included the traditional doctrine of the legitimacy of the positive discrimination (Aragoneses, S., Cubillo, I. J., Jaen, M., Manjón, A., Nuñez, J. and Requejo, M. T., 2006).

In connection with this question the Spanish Courts try to solve another interpretative problem which is the mutual aggressions between the spouses, with reciprocal slight harm. If we attend the literal meaning of the article 153 of the Spanish Criminal Code, it would be a felony this behavior if the author is a man, and misdemeanor if the author is a woman.

The answer in the sentences of the Provincial Courts have lied not impose the article 153 mentioned, because the fight between the couple is mutual accepted, or because, and this is the tendency with a higher support in the last times, the article 153 needs to be applied a subjective element, which is the sexist violence; or at least a factual situation of subjugation of one of the relatives on the part of the other (Valmaña, 2010-b). Nevertheless the mentioned problems on the interpretation of the abuse felony in the Spanish Criminal Code, the fact is the efficiency of this rule is limited, and some authors have pointed better options in the social control of this crime (Lamarca and Alonso, 2008).

\section{CONCLUSION}

The short timeline of the crime of abuse in the Spanish Law makes not easy to define the figure with the clarity of the classic felonies. The legal doctrine mission will be to detect the failures on the application of this crime and propose viable solutions. The mission of the jurisprudence would be to find solutions within the precise limits of the legality principle scope. In any case, the legislator should refine the technique that makes the harmonic integration of the spirit and letter of the law possible.

\section{AUTHOR INFORMATION}

Silvia Valmaña Ochaita, PhD in Law (Cum Laude) and Degree in Law (Extraordinary Award) by University of Alcalá de Henares. Associate Professor at Public and Company Law Department. Faculty of Social Sciences of Cuenca. University of Castilla-La Mancha (Spain). E-mail: Silvia.Valmana@uclm.es.

Research Interest: Penitentiary Law, Women and Law, Patrimonial and Economic Crimes, Tourism, Educational, and DNA on Trial.

\section{REFERENCES}

1. Acale, M. (1999): El delito de malos tratos físicos y psíquicos en el ámbito familiar. Tirant Monografías. Valencia (Spain).

2. Alonso, A. and Lamarca, C. (2008): "Sobre la constitucionalidad del artículo 153.1 del Código Penal”, in La Ley, n. July, $28^{\text {th }}$.

3. Aragoneses, S., Cubillo, I. J., Jaen, M., Manjón, A., Nuñez, J. and Requejo, M. T. (2006): Tutela judicial frente a la violencia de género. Colex, Madrid. (Spain).

4. $\quad$ Cortés, E. (2000): El delito de malos tratos familiares. Nueva regulación. Ed. Marcial Pons. Madrid (Spain).

5. Faraldo, P. (2004): "Razones para la introducción de la perspectiva de género en Derecho penal a través de la Ley Orgánica 1/2004, de 28 de diciembre, sobre medidas de protección integral contra la violencia de género", in Revista Penal, n. 17.

6. $\quad$ Larrauri, E. (2007): Criminología crítica y violencia de género, Ed. Trotta, Madrid (Spain).

7. Observatory Against Domestic Violence And Gender-Based Violence, General Counsel of the Judiciary, (2010). Retrieved from http://www.poderjudicial.es/eversuite/GetRecords?Template=cgpj/cgpj/principal.htm. 
8. State Observatory Of Violence On Women. Ministry for Health, Social Policy and Equality. (2010). III Anual Report of The State Observatory Of Violence On Women (Executive Report). Retrieved from http://www.migualdad.es/ss/Satellite?blobcol=urldata\&blobheader=application\%2Fpdf\&blobheadername $1=$ Contentdisposition\&blobheadervalue $1=$ inline\&blobkey=id\&blobtable=Mung oBlobs\&blobwhere $=1244653592435 \&$ ssbinary $=$ true

9. Valmaña, S. (2000): "El delito de malos tratos", in RODRIGUEZ, C. y VALMAÑA, S. (Ed.): La mujer como víctima: Aspectos jurídicos y criminológicos. Ediciones de la Universidad de Castilla La Mancha, Cuenca.

10. Valmaña, S. (2010-a): "Mujer y violencia: algunas cuestiones sobre el método, objeto y evolución políticocriminal", in Documentos de Trabajo. Seminario Permanente de Ciencias Sociales, n. 6. Retrieved from http://www.uclm.es/CU/csociales/pdf/documentosTrabajo/2010/2010-6.pdf

11. Valmaña, S. (2010-b): "La respuesta penal a la violencia contra las mujeres. El delito de malos tratos del artículo 153 del código penal español”, in Violencia contra las mujeres. Un enfoque jurídico. Zurilla, M.A. y Domínguez, M.P. (Ed.). Septem Ediciones. Oviedo (Spain). 


\section{NOTES}

